Southern Methodist University

SMU Scholar

Faculty Journal Articles and Book Chapters

Faculty Scholarship

1983

\title{
A Shared Values Approach to Jurisdictional Conflicts in International Economic Law
}

Bernhard Grossfeld

University of Munster

C. Paul Rogers III

Southern Methodist University, Dedman School of Law

\section{Recommended Citation}

Bernhard Grossfeld \& C. Paul III Rogers, A Shared Values Approach to Jurisdictional Conflicts in International Economic Law, 32 Int'I \& Comp. L.Q. 931 (1983)

This document is brought to you for free and open access by the Faculty Scholarship at SMU Scholar. It has been accepted for inclusion in Faculty Journal Articles and Book Chapters by an authorized administrator of SMU Scholar. For more information, please visit http://digitalrepository.smu.edu. 


\title{
A SHARED VALUES APPROACH TO JURISDICTIONAL CONFLICTS IN INTERNATIONAL ECONOMIC LAW
}

\author{
By \\ Bernhard Grossfeld* and C. Paul Rogers**
}

\section{INTRODUCTION}

Discussions of multinational economic law often refer to the extraterritorial aspects of domestic law, such as the antitrust and securities laws of a country. Difficulties arise when a country attempts to apply its domestic laws to acts done abroad. For example, the United States antitrust laws might well be applied to a European price-fixing cartel engaged in exporting goods to the United States. Such situations engender international tensions beyond the economic, political and diplomatic clashes we aré accustomed to in traditional conflict of laws circumstances.

The international debate started and now focuses upon the subjectmatter jurisdictional standards of United States courts in enforcing American antitrust and securities laws abroad. ${ }^{1}$ It is disconcerting that the tensions are particularly acute between the United States and its liberal democratic allies. Interestingly, the initial conflict occurred between the United States and the United Kingdom, countries with a history of close cultural and political ties. ${ }^{2}$

That the United States is in the centre of the storm is not surprising. Historically, the concept of protection of a free market economy, while originating in European legal systems ${ }^{3}$ has been most intensively pursued in the United States. ${ }^{4}$ Further, American securities laws initiated a pattern

* Professor of Law, University of Münster.

** Associate Professor of Law, Southern Methodist University.

The authors are grateful to Jeswald Salacuse for his comments on an earlier draft of this paper.

1. See e.g. Norton, "Extraterritorial Jurisdiction of US Antitrust and Securities Laws" (1979) 28 I.C.L.Q. 575; Sornarajah, "The Extraterritorial Enforcement of US Antitrust Laws: Conflict and Compromise" (1982) 31 I.C.L.Q. 127

2. See United States v. Imperial Chemical Industries Ltd., 100 F. Supp. 504 (S.D.N.Y. 1951), and British Nylon Spinners Ltd. v. Imperial Chemical Industries Ltd. [1953] Ch. 19 (CA); [1955] Ch. 37.

3. Grossfeld, "Zur Kartellrechtsdiskussion vor dem erstem Weltkrieg", in Coing/Wilhelm (Eds.), Wissenschaft und Kodifikation des Privatrechts im 19. Jahrhundert (1979), Vol.4, p.255.

4. See e.g. W. Letwin, Law and Economic Policy in America (1965); H. Thorelli, Federal Antitrust Policy (1959). 
of corporate governance that has only recently been followed in other legal systems. ${ }^{5}$ Likewise, the problems of international application of these kinds of laws were first considered in United States courts. ${ }^{6}$ Beyond these historical factors the political and economic strength of the United States gives its legal concepts wider ranging impact internationally.

In addition, the American methods of enforcement are viewed by other countries as particularly aggressive. ${ }^{7}$ The pervasive use of private lawsuits is abhorred abroad. Commonplace aspects of the American judicial system such as liberal pre-trial discovery, punitive and treble damages, contingency fee arrangements and the defendant's role as a witness differ from other common and civil law systems and are therefore viewed with suspicion. The American jury system, under which jurors serve as the arbiters of facts and control the granting and the amount of money damages, is viewed as inherently biased in favour of the private American plaintiff.

Lord Denning expressed this common sentiment in Smith Kline and French Laboratories Ltd. v. Bloch ${ }^{8}$ in the Court of Appeal:

As a moth is drawn to the light, so is a litigant drawn to the United States. If he can only get his case into their courts, he stands to win a fortune. At no cost to himself and at no risk of having to pay anything to the other side. The lawyers there will conduct the case "on spec" as we say-or on a "contingency fee" as they say. The lawyers will charge the litigant nothing for their services but instead they will take 40 per cent. of the damages - if they win the case in court-or out of court on a settlement. If they lose, the litigant will have nothing to pay to the other side. The courts in the United States have no such costs deterrent as we have. There is also in the United States a right to trial by jury. These are prone to award fabulous damages. They are notoriously sympathetic and know that the lawyers will take their 40 per cent. before the plaintiff gets anything. All this means that the defendant can be readily forced into a settlement. The plaintiff holds all the cards.

Similar reactions can be found in the legal literature of other Western nations. ${ }^{9}$

These countries also resent what they regard as the use of private suits to enforce American public and economic policies abroad. The American system which encourages the private redress of wrongs of its citizenry

5. See Tunc, "A French Lawyer Looks at American Corporation Law and Securities Regulation" (1982) 130 U.Pa.L.Rev. 757, at p.759.

6. American Banana Co. v. United Fruit Co., 213 U.S. 347 (1909); United States v. Aluminum Co. of America, 148 F.2d 416, 443-445 (2d Cir. 1945); Schoenbaum v. Firstbrook, 405 F.2d 200 (2d Cir. 1968), cert. denied, 395 U.S. 906 (1969).

7. Grossfeld, "Probleme der Rechtsvergleichung im Verhältnis Vereinigte Staaten von AmerikaDeutschland" (1975) 39 RabelsZ. 5.

8. Lord Denning in Smith Kline and French Laboratories Ltd. and Another v. Bloch, The Times, May 17, 1982 (1980 S No.6514 (Transcript: Association) May 13, 1982).

9. Cf. Von Hülsen, "Gebrauch und Missbrauch US-amerikanischer 'pre-trial discovery' und die internationale Rechtshilfe", in Recht der Internationalen Wirtschaft (1982), p.225. 
through the judiciary often has no corollary in other countries. ${ }^{10}$ They blame the US generated private suit as circumventing their traditional defences against foreign political or administrative intervention. The private suit is regarded as State activity hidden under the rubric of private action. ${ }^{11}$ It is not that foreign countries misunderstand the American values which promote the private litigant; it is that they resent the exportation of the methods of American enforcement through "private attorneys general". The result is a clash of American legal institutions with foreign legal systems and their underlying values. ${ }^{12}$

The foreign defensive reactions to American extraterritoriality are thus understandable and are in fact invited by the operation of the American legal system. American law recognises the defences of foreign compulsion, ${ }^{13}$ Act of State ${ }^{14}$ and sovereign immunity. ${ }^{15}$ American law does not, however, recognise as a legal defence foreign concepts, such as informal rules, that are unfamiliar to the American socio-legal culture. ${ }^{16}$

The result is that citizens of a liberal (democratic) State have fewer defences to an American lawsuit than those of States of paramount government control. Citizens of State controlled countries are likely to be insulated from American litigation by claiming the US created defences of foreign compulsion and the like even though the values and norms of the countries are disparate. Also, the relative openness of judicial systems in democratic countries presents more opportunities for conflict than legal systems that are closed to foreign concerns. The result is greater opposition to American antitrust and securities laws in those States most closely aligned ideologically to the United States, for example, England, Canada and Australia, than in non-democratic nations where little thought is given to the extraterritorial application of American laws. Thus, a paradox arises

10. Grossfeld, op. cit. supra $\mathrm{n} .7$, at p.14.

11. Cf. Grossfeld, "Multinationale Korporationen im Internationalen Steuerrecht" (1978) 18 Berichte der Deutschen Gesellschaft für Völkerrecht 72, at p.122.

12. See Griffin, "The Incompatibility of International Accommodation and Private Attorneys General" (1982) 14 Case W. Res. J. Int. L. 31; cf. Consumers Union v. Kissinger, 506 F.2d 136 (D.C. Cir. 1974), cert. denied, 421 U.S. 1004 (1975).

13. See e.g. Ricks, "International Law-Antitrust Law-Immunities to Extraterritorial Application of United States Antitrust Law" (1978) 12 J. Int. \& Econ. L. 487; Meal, "Governmental Compulsion As a Defense Under United States and European Community Antitrust Law" (1981) 20 Colum. J. Transnat. $L$. 51.

14. See e.g. Timberg, "Sovereign Immunity and Act of State Defenses: Transnational Boycott and Economic Coercion" (1979) 6 Revue Suisse du droit international de la concurrence 20; International Association of Machinists v. OPEC, 649 F.2d 1354 (9th Cir. 1981).

15. See e.g. Cooper, "Act of State and Sovereign Immunity: Further Inquiry" (1980) 11 Loy. U. Chi. L. J. 193; Note, "The Applicability of the Antitrust Laws to International Cartels Involving Foreign Governments" (1982) 91 Yale L.J. 765.

16. See e.g. Craig, "Application of Trading with the Enemy Act to Foreign Corporations Owned by Americans: Reflections on Fruehaufv. Massardy" (1970) 83 Harv. L. Rev. 579, at p.596. 
whereby the constituents of American allies are most directly affected by the extraterritoriality of the American legal system.

The initial consequence is that the liberal States feel pressured to invent defence mechanisms that are cognisable in the American legal system. These defences include barring plaintiffs' access to material information and refusing to enforce US judgments. It is not surprising that foreign blocking statutes are epidemic. ${ }^{17}$ They are simply home-grown remedies against a perceived invasion of the sanctity of the promulgating State's legal structure. The statutes are in reality generated by the US and are a natural, predictable consequence of the US approach to subject-matter jurisdiction.

If these developments continue, the free world will soon be divided between States asserting extraterritorial application of their laws and States reacting with reciprocal intensity. Many jurisdictions, including West Germany ${ }^{18}$ and the European Economic Community, ${ }^{19}$ are heavily influenced by the American example of liberal extraterritorial claims. Others are following the Canadian and Dutch example with blocking statutes. ${ }^{20}$ In the long run most countries may, depending on the issue and the national interest involved, stand on both sides of the dispute. For example, the US Congress has considered enacting its own blocking statute to protect its populace against the asserted extraterritorial jurisdiction of foreign laws. ${ }^{21}$ The consequences of these developments in international economic law are inherently destructive and may lead to a disruption, politically and legally, of the international community, particularly between countries sharing similar ideologies and values.

The simplest solution to the problems is to look first to foreign jurisdictions to seek a more co-operative attitude. There is little hope, given the current state of affairs, that foreign States, already on the defensive, will take the first step to adopt such an attitude. Another approach may be more successful though more painful to the United

17. Blocking statutes are laws designed to take advantage of the foreign government compulsion defence by prohibiting such things as disclosure, copying and inspection or removal of documents located in the territory of the cnacting Statc in compliance with orders of forcign authoritics. Sec c.g.: United Kingdom-Protection of Trading Interests Act 1980; France-Law No.80-538 of July 16, 1980 [1980] J.O. 1799. supcrseding Law No.68-678 of July 26, 1968 [1968] J.O. 7267; South Africa-Protection of Businesses Act. Act 99 of 1978, as amended by the Protection of Businesses (Amendment) Act. Act 114 of 1980. Sce also Comment. "Shortening the Long Arm of American Antitrust Jurisdiction; Extratcrritoriality and the Forcign Blocking Statutes" (1982) 28 Loy. L.Rev. 213; Notc. "Foreign Nondisclosure Laws and Domestic Discovery Orders in Antitrust Litigation" (1979) 88 Yale L.J. 612.

18. S.98, subs.(2), German Statute on the Restriction of Trade (Gesetz gegen Wettbewerbsbeschränkungen).

19. Art.85, EEC Treaty; cf. Vagts, "A Turnaround in Extraterritoriality" (1982) 76 A.J.I.L. 591.

20. See supra $\mathrm{n} .17$, and accompanying text.

21. See S.1592, 97th Cong., Ist Sess. (1981); H.R.4339, 97th Cong., 1st Sess. (1981). 
States: if the paradox began domestically through broad jurisdictional claims for a sovereign law, then arguably the solution for the paradox caused thereby should also start at home by taking foreign interests more seriously at the outset. The US Supreme Court strongly voiced this attitude in $M / S$ Bremen v. Zapata Off-Shore Company:

The expansion of American business and industry will hardly be encouraged if, notwithstanding solemn contracts, we insist on a parochial concept that all disputes must be resolved under our laws and in our courts .... We cannot have trade and commerce in world markets and international waters exclusively on our terms, governed by our laws and resolved in our courts. ${ }^{22}$

However, in practice US courts have frequently paid little more than lip service to the Zapata language, and have not sufficiently focused upon or understood foreign interests. ${ }^{23}$

\section{POSSIBLE APPROACHES}

THE paradox has increasingly generated diplomatic attempts at accords beginning with the Rogers-Fulton agreement in $1959^{24}$ and including the American-German treaty of co-operation about restrictive trade practices $^{25}$ and most recently the American-Australian treaty. ${ }^{26}$ Further attempts have occurred in the United Nations through the newly adopted, multilaterally agreed Equitable Principles and Rules for the Control of Restrictive Business Practices Proclamation. ${ }^{27}$ The treaties and accords, however, do not yet cover important American trading partners such as the UK and France. The United Nations declarations are not intended to be legally binding and fail to cover all extraterritorial legal problems. Conflicts in legal systems differ depending upon the substantive law involved; the diplomatic accords, treaties and United Nations proclamations are either

22. 407 U.S. 1 (1972).

23. See e.g. In re Grand Jury Proceedings, United States v. Bank of Nova Scotia, 691 F.2d 1384 (11th Cir. 1972).

24. See Campbell, "The Canada-United States Antitrust Notification and Consultation Procedure" (1978) 56 Can. B. Rev. 659; Henry, "The United States Antitrust Laws: Canadian Viewpoint" [1970] Can. Y.B.I.L. 249.

25. See US-German Agreement on Antitrust Co-operation (1977) 11 J.W. Trade L. 95.

26. On June 29, 1982, an agreement between the US and Australia concerning principles of antitrust enforcement was initiated by Attorneys Gencral Smith and Durack. Art. 1 of the agrecment provides for notification by each country of policy changes or investigations which would have an impact on the other. Art. 2 establishes consultation procedures for conflicts in law, policy or national interest:' The Australian Government may request written clarification of enforcement intentions through FTC proceedings, and the Department of Justice may participate by reporting the outcome of any consultation procedures in private antitrust suits which concern Australian policy or law. Text of Agreement Between the Government of the United States of America and the Government of Australia Relation to Cooperation of [sic] Antitrust Matters, 43 Antitrust \& Trade Reg. Rep. (BNA) 36 (July 1, 1982). See also 42 Antitrust \& Trade Reg. Rep. (BNA) 1081 (May 20, 1982).

27. Restrictive Business Practices Code, UN Doc. TD/RBP/Conf./10/Rev.1 (1980). 
non-specific in nature or cover only antitrust or competition principles. Although worthwhile, they do not appear to be a panacea.

Traditionally, in the absence of diplomatic co-operation, the judiciary alone is confronted with the resolution of the paradox. In the United States, the Alcoa effects test has in large measure shaped the courts' approach to extraterritoriality. ${ }^{28}$ More recently, however, American courts have viewed the effects test as a sometimes unwarranted intrusion upon foreign sovereignty and have resorted to an attempted balancing of competing interests. ${ }^{29}$ Yet American courts have disagreed both as to the standards to be applied and the methodology of the standard ${ }^{30}$ The balancing approach involves a weighing of interests on international, national and litigant scales. ${ }^{31}$ The result thus often seems arbitrary and has been described by the Ninth Circuit as a "judicial nightmare", 32 and by a District Court as an "unanswerable enigma". ${ }^{33}$ Further, an approach which requires an American judge to trade off foreign interests with United States interests in a suit in which the plaintiff is typically American and the defendant typically foreign is inherently suspect. ${ }^{34}$

The interest analysis approach was originally conceived for internal conflicts, i.e. States within the United States, where a much greater degree of homogeneity results in a more accurate appraisal of the other State's interest. The value of interest analysis wanes when it is applied to conflict of laws internationally. Then one is bound to view the foreign interests within the confines of his or her own legal system, resulting in a distorted perception of the foreign interest. ${ }^{35}$ Further attempts to improve the present methods and to provide a workable, manageable structural analysis are greatly needed.

Of course, all conflict of laws issues, whether domestic or international, involve an interest analysis. Competing interests are inherent in any

28. United States v. Aluminum Co. of America, 148 F.2d 416 (2d Cir. 1945).

29. Mannington Mills Inc. v. Congoleum Corp., 595 F.2d 1287 (3d Cir. 1979); Timberlane Lumber Co. v. Bank of America, 549 F.2d 597 (9th Cir. 1976).

30. See In re Uranium Antitrust Litigation, 617 F,2d 1248, 1295 (7th Cir. 1980).

31. See Rosenfield, "Extraterritorial Application of United States Laws: A Conflict of Laws Approach" (1976) 28 Stan.L.Rev. 1005.

32. Forsyth v. Cessna Aircraft Co., 520 F.2d 608, 609 (9th Cir. 1975); cf. Lüderitz, "Gerhard Kegel und das deutsche internationale Privatrecht" (1982) 46 Rabel2. 475, at p.484.

33. In re Paris Air Crash of March 3, 1974, 399 F. Supp. 732, 741 (C.D. Cal. 1975).

34. United Nuclear Corp. v. General Atomic Co. (No.50, 827, Santa Fe County, New Mexico, 1978), affd. 629 P.2d 23 I (N.M. 1980), reh. denied, 1980, cert. denied, 451 U.S. 901 (1981); cf. In re Grand Jury Proceedings, United States v. Field, 532 F.2d 404 (5th Cir. 1976), cert. denied, 429 U.S. 940 (1976).

35. Cf. Goble, "Nature, Man and Law" (1955) 41 A.B.A.J. 403, reprinted in Henson, Landmarks of Law (1960), p.36. For a recent critique of the American Law Institute's current attempts to redraft the interest analysis approach in Restatement form, see 45 Antitrust \& Trade Reg. Rep. (BNA) 97 (July 21, 1983). 
adversary process in law; in the international context, both private and governmental interests conflict in varying degrees. But it would be helpful to structure the analysis so that there are different levels of analysis for different levels of interest. Such a systematic approach would help to localise the concrete interests of a particular conflict situation and provide the parameters for detailed, focused analysis.

The issues we are concerned with arise in many contexts involving different fields of law. The problems range from bank secrecy to testimonial privileges, to the prohibition of rendering legal services by local lawyers, and to the disclosure of documents. Each issue obtains its substance from its particular legal environment. It would be somewhat reckless to take on each problem here. We intend to separate the issues and begin the discussion with a finite problem-the relevance of foreign bank secrecy laws as a defence to discovery orders in an American court. The choice is justified because the first foreign blocking provisions resulted from laws of this nature.

\section{FOREIGN MANDATORY RULES}

THE threshold question is whether the foreign bank secrecy law can be applied as law, as occurs for example with foreign tort law, or whether it can merely be used to demonstrate factual impossibility or hardship of performance. That is, will the court from which the discovery order emanates give full recognition to a foreign law which prohibits the exportation of bank documents or evidence and regards non-compliance with a discovery order as justified on that basis, or will it simply consider the foreign law as a possible factual barrier to document production? Two levels of analysis are mandated. In the first instance the interests of legislatures must be compared; the second focuses more on individual burdens.

Thus far American courts have tended to disregard the first possibility and focus on the second. For example, the Tenth Circuit position is that "foreign law may not control local law". ${ }^{36}$ This position may stem from a general distrust of foreign governmental claims and foreign penal laws. ${ }^{37}$ As Lord Mansfield stated: "No country ever takes notice of the revenue laws of another country."38 The US Supreme Court observed in an early

36. Arthur Andersen \& Co. v. Finesilver, 546 F.2d 338, 342 (10th Cir. 1976), cert. denied, 429 U.S. 1096 (1976). For a clear distinction, see Restatement, Foreign Relations Law of the United States (Revised), Tent. Draft No.3 (1982), sec.420, comment (f).

37. See E. Scoles and P. Hay, Conflict of Laws (1982), p.75.

38. Holman v. Johnson (1775) 98 E.R. 1120 (KB). 
decision that "the courts of no country execute the penal laws of another" ${ }^{39}$ The reasons for the distrust may arise from the more territorial nature of ${ }^{2}$ these laws as compared with private laws. More important, courts are uncertain of the values expressed by foreign governmental claims and penal laws. But these concerns have lessened both in the United States ${ }^{40}$ and in Europe,${ }^{41}$ because nations are more aware of the possibility of shared values with foreign States and recognise that these values may be expressed even in laws generally characterised as mandatory.

The rigid barriers against the application of foreign mandatory laws expressing governmental interests have been under attack in Europe during the last 20 years. ${ }^{42}$ For example, the West German Federal Court voided an insurance contract that violated a Nigerian statute prohibiting the export of native artifacts. ${ }^{43}$ The transport of the artifacts was insured by a German insurance company. German law was applicable through a choice of law clause in the contract. The court concluded that there was no insurable interest because the transport itself was illegal. The finding of illegality was technically based on West German public policy, ${ }^{44}$ but the interpretation of the court was sensitive to international concerns and to Nigerian interests. The court stated that

the circumvention of such a protective [Nigerian] statute must be regarded as reprehensible; it contradicts the interests of all people in the preservation of their cultural heritage in its original environment, an interest that according to modern standards must be generally respected. Certain basic convictions exist within the community of nations concerning the right of each country to protect its cultural heritage and regarding as reprehensible practices which interfere with this heritage; accordingly these practices must be prevented. ${ }^{45}$

Earlier, the same court expressed its willingness to apply American embargo rules in so far as these rules expressed values also held in West Germany. ${ }^{46}$

The West German approach towards foreign mandatory laws is gaining support ${ }^{47}$ Article 7 of the proposed European Convention on the Law

39. The Antelope, 23 U.S. (10 Wheat) 66, 123 (1825).

40. See c.g. Cohen, "Nonenforcement of Foreign Tax Laws" (1970) 11 Harv.Int.L.J. 1; Dachs, "Enforcement of Foreign Tax Judgments in the United States" (1980) 14 J.Int.L. \& Econ. L. 291.

41. Grossfeld, op. cit. supra n.11, at p.146.

42. Grossfeld, Praxis des Internationalen Privat- und Wirtschafisrechts (1975), p.95.

43. Entscheidungen des Bundesgerichtshofs in Zivilsachen (BGHZ) $59,82$.

44. S.138, German Civil Code (Bürgerliches Gesetzbuch).

45. BGHZ 59, supra n.43, at p.85.

46. Ibid. p. 167; [1962] Neue Juristische Wochenschrift 1437:

47. Heini, "Dic Anwendung wirtschaftlicher Zwangsmassnahmen im Internationalen Privatrecht" (1982) 22 Berichte der Deutschen Gesellschaft für Völkerrecht 37. But cf. Grossfeld, op. cit. supra n.l1. 
Applicable to Contract Obligations provides, under the heading "Mandatory Laws": 48

1. When applying under this Convention the law of a country, effect may be given to the mandatory rules of the law of another country with which the situation has a close connection, if and in so far as, under the law of the latter country, those rules must be applied whatever the law applicable to the contract. In considering whether to give effect to these mandatory rules, regard shall be had to their nature and purpose and to the consequences of their application or non-application.

2. Nothing in this Convention shall restrict the application of the rules of the law of the forum in a situation where they are mandatory irrespective of the law otherwise applicable to the contract.

The mandatory rules referred to above contain domestic values that are so strong as to make the norm of the rule compulsory in nature even if a legal relationship may be governed by the law of another country. Application of mandatory rules cannot be avoided by choice of law clauses because of the rule country's overriding interest in the execution of the mandatory rule. The interests of the host country are so paramount that it is unwilling to defer the rule's application to normal choice of law mechanics.

With this background it is not surprising that European commentators favour application of foreign antitrust law by domestic courts. A leading German commentator has stated that "as a general rule foreign antitrust law is applicable whether or not it serves private purposes". ${ }^{49}$ This amounts to a full recognition of applicability of foreign antitrust laws.

The deference to foreign mandatory law has at least some merit. Where nations share common values, the manner of expressing these values through law should not be determinative. The nature of the characterisation should not be the focus; rather the inquiry should focus on whether the law expresses typical international interests rather than local chauvinistic values. In other words, the decisive factor should be whether the mandatory rule expresses values shared in common and which the receiving country is itself willing to protect. The search for similarities in values, even expressed differently, and an understanding of the foreign environment should take precedence over superficial differences.

\section{TESTIMONIAL PRIVILEGE AND FOREIGN JUDGMENTS}

THE solutions found where a claim of testimonial privilege based on foreign

48. (1980) XIX I.L.M. 1492. Sec also Schultsz, "Dutch Antecedents and Parallels to Article 7 of the EEC Contracts Convention of 1980" (1983) 47 RabelsZ. 267.

49. Rehbinder, in Gesetz gegen Wettbewerbsbeschränkungen (Immenga and Mestmäcker (Eds.) 1982), chap.7, s.98, subs.(2), No.273. 
law is asserted are illustrative. A conflict of this nature arises when the evidentiary rule of the forum differs from another jurisdiction, such as often occurs with the privilege against disclosure of confidential information. ${ }^{50}$ Where the conflict arises domestically within the United States the interests of three jurisdictions may be involved-that of the State whose law governs the underlying claim, the State having the most significant relationship with the substance of the testimony, and the forum State. ${ }^{51}$ The Restatement approach, which has heavily influenced the courts, ${ }^{52}$ focuses upon which forum has the most significant relationship with the communication which is the subject of the asserted privilege. ${ }^{53}$

Where the privilege claimed is based on the law of another country, similar interests are involved. Article 11 of the Hague Convention on the Taking of Evidence Abroad in Civil or Commercial Matters unconditionally entitles a witness to claim all the privileges available under the domestic law of the State of execution (where the testimony is sought). ${ }^{54}$ The Hague Convention approach reflects the shared values approach because it recognises foreign standards which are shared by nations. Further, the Hague Convention incorporates a concept of territoriality. Quite recently, the European Court of Justice adopted a similar approach when faced with an attorney-client privilege question under European Community law. ${ }^{55}$ Although there was no statutory foundation for it, the Court nevertheless recognised the privilege because it expressed values that all Member States held in common. The Court emphasised that the independence and ethical responsibilities of lawyers were similar throughout the European Community as a consequence of a common, shared legal tradition. ${ }^{56}$

Similar considerations govern the recognition of foreign judgments. The liberal recognition concept depends on whether the foreign procedure and foreign law correspond by and large to the local value system. ${ }^{57}$ Judge Higginbotham characterised this concept of recognition as follows:

Where, as here, the rendering forum's system of jurisprudence has been a model for other countries in the free world, and whose judges are of unquestioned integrity

50. Ibid. No. 272.

51. See E. Scoles and P. Hay, op. cit. supra n.37, at p.397.

52. See also ibid. pp.397-400.

53. Restatement, Second, Confict of Laws (1971), secs.138, 139.

54. March 18, 1970, 23 U.S.T. 2555, T.1.A.S. No.7444.

55. AM \& $S$ Europe Ltd. v. Commission of the EC, Case 155/79 [1982] 2 C.M.L.R. 264; F.S.R. 474; The Times, May 20, 1982.

56. The approach could presumably be extended to include lawyers outside the European Community, including American attorneys, who represent similar legal traditions.

57. Cf. Von Mehren, "Recognition and Enforcement of Sister State Judgments" (1981) 81 Colum. L. Rev. 1044. 
independent of the political winds of the moment, the judgment rendered is entitled to a more ministerial, less technocratic recognition process. ${ }^{58}$

\section{FOREIGN BANK SECRECY LAWS}

ARGUABLY the shared value approach is valid with respect to conflicts generated by foreign bank secrecy laws. The foreign law, of course, is not to be respected if it is exclusively directed against parties outside the jurisdiction of the foreign State. For example, Article 273 of the Swiss Criminal Code prohibits the giving of information only to non-Swiss authorities. ${ }^{59}$ The West German Bundesfinanzhof (the highest German court in taxation matters) declared that "no other State must recognise the effects of this Swiss penal provision" 60 because Switzerland cannot expect another country to follow rules of law that are applied discriminatorily against foreign States.

In addition, foreign bank secrecy laws should only be applied as law to the extent they are applied as law in the foreign country itself. Bank secrecy which is not a defence to local investigatory procedures should not bar foreign authorities from proceeding. In United States v. Field ${ }^{61}$ the defendant sought to prevent a US grand jury from obtaining information in the Cayman Islands that would have been obtainable by officials there for their own investigatory purposes. The Fifth Circuit, in denying the defence, held that

[s]ince the general rule appears to be that for domestic investigations such information would be obtainable, we find it difficult to understand how the bank's customers' rights of privacy would be significantly infringed simply because the investigating body is a foreign tribunal. ${ }^{62}$

Only recently the Eleventh Circuit took a similar position with respect to the Bahamian bank secrecy law:

It is incongruous to suggest that a United States court afford greater protection to the customers' right of privacy than would a Bahamian court simply because this is a foreign tribunal. ${ }^{63}$

Apart from these principles, foreign bank secrecy laws should be recognised as law when they correspond to similar provisions in the forum country's law. Presumably, the similarity would reflect shared values in the

58. Hunt v. BP Exploration Co. (Libya) Ltd., 492 F. Supp. 885 (N.D. Tex. 1980).

59. Bindschedler, Der strafrechtliche Schutz wirtschaftlicher Geheimnisse (1981).

60. Recht des Internationalen Wirtschaft (1982), p.176.

61. 532 F.2d 404 (5th Cir. 1976), cert. denied, 429 U.S. 940 (1976).

62. Ibid. p.408; see United States v. First National City Bank, 399 F.2d 857 (2d Cir. 1972).

63. In re Grand Jury Proceedings, United States v. Bank of Nova Scotia, 691 F.2d 1384, 1391 (11th Cir. 1982). 
two legal systems. Small deviations reflecting local peculiarities should not disturb the recognition of the foreign law.

The final situation presents the hardest choices. It occurs when the foreign secrecy law has no forum State counterpart or goes substantially beyond the forum State's laws. Initially, it would appear that shared value analysis would bar application of the foreign law since no counterpart as an expression of a shared value exists. But the shared value analysis should not end there because the lack of a statutory counterpart does not necessarily preclude the existence of shared value systems. The analysis should focus upon whether changing circumstances in the forum State would produce a similar reaction within the existing values of that State. That is, if the foreign law were transferred to the American system, would it be thought of as possibly compatible with that system or would it be rejected as inconsistent with basic precepts of the domestic law? Purely chauvinistic values would not be tolerated but institutional reactions which could conceivably mirror that of the forum State would be applied.

The shared value approach merely provides a structural framework for analysis of the hard cases. ${ }^{64}$ It is not definitive in nature because it is non-specific, ${ }^{65}$ discretionary and does not totally insulate the forum judge from an interest analysis which must consider the interest (i.e. values) of a foreign State. For example, the Second Circuit in Trade Development Bank v. Continental Insurance $C o{ }^{66}$ upheld a defence based upon a Swiss bank secrecy statute because the information sought was of minor importance to the plaintiff. ${ }^{67}$ Thus, recourse to the more traditional interest analysis cannot be completely avoided and may often facilitate a conflict of laws resolution where the interests of one party are clearly

64. The practical constraint of the legislative process on a shared values (or interest analysis) approach should not be overlooked. That is, a court attempting to determine whether forcign law should be applied may not have the authority to supersede its own law because of the legislative mandate under which it is working. Thus, even though a shared values approach might otherwise result in recognition of the foreign law, legislatively imposed restrictions may preclude its operation. Courts in Western countries are not independent of their legislatures; therefore we should not expect too much from our judicial systems in resolving legal conflicts.

65. The non-specificity in identifying and analysing values may pose real problems in some jurisdictions. For example, a court utilising the shared values approach may focus on procedural rather than substantive differences. An English court faced with an American privatc treble damage antitrust action may decline to apply American law because of its aversion to the private enforcement of laws perpetuated by the American legal system. If the same court focused on the substance of the lawsuit, the shared values of both countries in promoting competition would be paramount and the foreign (American) law would be applied. In that situation it should be obvious that the values shared in the substantive law (promotion of competition, etc.) are more significant than the procedural disparities of enforcement.

66. 469 F.2d 35 (2d Cir. 1972).

67. See generally SEC v. Banca Della Suizzera ltaliana, 92 F.R.D. 111, 114 (S.D.N.Y. 1981). See also Restatement of the Law, Foreign Relations Law of the United States (Revised). Tent. Draft No.3 (1982), sec.419. 
disproportionate to the interests of the country whose law causes the conflict. Another exception should be made if the foreign bank law was primarily adopted for foreign transactions which circumvent laws of a given State. The history and tradition of the foreign bank secrecy law would be of importance in this context. ${ }^{68}$

\section{SHARED VALUES AND THE INTEREST ANALYSIS}

As noted, a shared values approach inherently gives greater deference to foreign mandatory law than does an interest analysis; it thus may frequently be outcome-determinative. The shared values approach does not insulate the court from evaluating the interests of the foreign State. It does, however, shift the court's initial focus from weighing the interest involved to considering the values underlying the foreign law. If similar values are found, the rationale for refusing to apply the foreign law diminishes profoundly unless the foreign interest in the matter before the court is insubstantial compared with the interest of the forum State. The balancing of interests cannot be avoided but the emphasis on shared values assures that the foreign law interests are not as likely to receive short shrift as under a traditional interest analysis.

It is likely that a finding of shared values would influence a court's subsequent interest analysis. That is, a judicial determination that the foreign mandatory law expressed values shared by the forum jurisdiction, even though the laws of the two States differed, would seemingly make it more difficult for the court then to find that the interests of the foreign jurisdiction are inferior to the forum. The interest analysis could still bar the application of foreign law, however, because the focus there should be on the circumstances peculiar to the facts of the case.

Thus, in a case involving a foreign bank secrecy law which blocks the discovery of information or transmission of documents necessary to litigation brought in the United States, the shared value approach would first focus on whether the reasons and policy for the bank secrecy law have, or would have in similar circumstances, a counterpart in the United States. The initial trade-off of foreign and domestic interests is avoided. If a shared value is determined to exist, the foreign secrecy law should apply unless the foreign interest is demonstrably inferior to the forum interest. The requirement of "demonstrable inferiority" in the trade-off portion of 
the analysis would help prevent undue subjectivity by the forum court in the balancing of interests. It would also preclude a court from circumventing the shared value portion of the analysis by giving inordinate weight to the interests of the forum.

We are forthright in urging the shared values approach as a means to increase forum court tolerance of discordant foreign laws. The approach incorporates a quid pro quo attitude; in looking for shared values, considerations of how the forum jurisdiction would hope to be treated if the situation were reversed arise. We do, however, recognise that a shared value approach may, in some cases, result in less tolerance of foreign mandatory law than would an interest analysis. If no shared values can be found, resort to an interest analysis would be unnecessary, even though the balancing of other factors might favour application of foreign law. Thus, the effect may be to preclude application of foreign law although an interest analysis would have reversed the decision.

An alternative means of avoiding this prospect is to require an interest analysis even though no shared values can be found. This approach would presumably maximise forum deference to foreign laws and guard against an unduly narrow search for shared values. While the choice is a difficult one, we would resort to an interest analysis only when shared values in foreign mandatory rules are found. We question whether deference to a foreign mandatory law is appropriate unless shared values, as we have broadly defined them, exist. Application of the laws of State controlled jurisdictions, where shared values could rarely be found, might be favoured if an interest analysis inevitably followed the consideration of shared values. The dominant and pervasive State interest involved might persuade some courts, under an interest analysis, to apply foreign law more liberally there than when democratic jurisdictions are involved. Further, at least with regard to Western countries, we doubt that many cases exist where an interest analysis would support application of foreign mandatory law although shared values were lacking.

\section{A GENUINE LINK}

ONCE the shared value analysis has demonstrated that a foreign mandatory law is generally applicable, a genuine link between the involved facts and the foreign State must be shown to justify application of the foreign law in the specific instance before the court. The genuine link concept, as originally articulated in the Nottebohm case, ${ }^{69}$ places a cognisable limit on

69. Nottebohm Case [1955] I.C.J. Rep. 4. 
the extraterritorial reach of law. It is today recognised as a precondition to the application of any other State's law.

With regard to bank secrecy laws, we suggest that a genuine link of sufficient strength exists with the State in which the bank has its seat-that is, its central administration. Thus, a Swiss bank should be able to invoke the Swiss bank secrecy law in a jurisdiction foreign to it if the bank secrecy law meets the standards of the shared value analysis.

An exception should exist for acts done within the forum State, for example through an agent or subsidiary or through exchange transactions in the forum State. There the interests of the forum State normally exceed those of the foreign State irrespective of a shared value analysis. These genuine link proposals seem to correspond to the approaches governing testimonial privilege conflicts which, according to the Restatement, should be governed by the law of the State where the confidential communication was made. ${ }^{70}$

\section{APPLICATION OF FOREIGN LAW AS FACT}

IF foreign law cannot be applied as law because of a lack of a shared value or of a genuine link, it might nevertheless have a factual influence on the result of the litigation. Foreign law might for instance make the performance of an act required under the law of the forum State factually impossible for the actor. For example, foreign secrecy laws often carry penal sanctions for disclosure of confidential information. Thus, an American discovery order requiring confidential information subject to the foreign law would create hardship against the party having knowledge of the information. Starting with the Interhandel decision, ${ }^{71}$ the discussion of the application of foreign law in the United States has centered largely on impossibility and hardship. Unfortunately, the analysis has often confused application of foreign law as law with application of foreign law as fact. ${ }^{72}$

On this second level, the analysis becomes more subjective and should focus upon the circumstances of the individual party who faces conflicting rules. Initially, inquiry should be made as to whether compliance with the forum's order would result in a penalty abroad. The possibility that the existing foreign sanction might be waived because of the nature of and

70. Restatement of the Law, Foreign Relations Law of the United States (Revised), Tcnt. Draft No.3 (1982), sec.419, comment (c); In re Ampicillin Antitrust Litigation, 81 F.R.D. 377, 391 (D.C.D.C. 1978).

71. Société Internationale v. Rogers, 357 U.S. 197 (1958).

72. Cf. Restatement of the Law, Foreign Relations Law of the United States (Revised), Tent. Draft No.3 (1982), sec.420, 1c, 2cc; United States v. Vetco Inc., 644 F.2d 1324 (9th Cir. 1981), cert. denied, 454 U.S. 1098 (1981). 
hardship created by the forum's order should not be overlooked. ${ }^{73}$ But the probability of a harsh foreign sanction does not end the analysis-it ripens the additional question of risk allocation, that is, should the forum State bear ultimately the risk of the foreign sanction? It may be that the forum court will find that the risk should remain where it falls, on the party facing the conflicting rules. In United Nuclear Corp. v. General Atomic Corp., the New Mexico Supreme Court correctly placed the risk of non-compliance on the defendant because the defendant knew that such a conflict could occur in the context in which it was doing business. ${ }^{74}$ The court stated that

$[w]$ hen a party places documents outside this country with the expectation that production of those documents will be frustrated in litigation here, the strong policy in favor of broad discovery dictates that that party bear the consequences of the dilemma created by the realization of its expectations. ${ }^{75}$

Thus the individual or "poor guy"must bear the brunt of the conflict where he has gambled or knowingly placed himself in a situation where the laws of two countries conflict.

The private party may, of course, become involved in a conflict situation unknowingly, either through surprise or the subsequent enactment of foreign legislation, as for example a blocking statute. But even where an individual has not knowingly assumed the risk of application of a foreign law, the forum State may still seek execution of its order. It can be argued in appropriate cases that the foreign State should relieve the individual of the burden of the conflict or compensate for damages incurred. If the foreign State does not want to waive applicability of its law, the conflict should be resolved between the foreign State and the individual. This approach is particularly appropriate where the individual is a citizen of the foreign State.

\section{CONCLUSION}

THE external application of a sovereign's laws has creatéd a paradox in the free world. The paradox is destructive of international relations, economically and politically. This paper has attempted to delineate a structural and contextual framework for dealing with the paradox by separating the areas of conflict and proposing a methodology of analysis for each. A distinction has been drawn between application of foreign law as law and as fact by

73. See Lowenfeld, "Sovereignty, Jurisdiction, and Reasonableness: A Reply to A. V. Lowe" (1981) 75 A.J.I.L. 629, at p.631.

74. United Nuclear Corp. v. General Atomic Co., 629 P.2d 231 (N.M. 1981), reh. denied, 1980, cert. denied, 451 U.S. 901 (1981).

75. 629 P.2d 231 , at p. 301 . 
evoking recent European thought. We have focused our methodology on an attempt to match the shared values of Western sovereigns in conflict of laws resolution. The shared values approach incorporates, rather than precludes, an interest analysis. However, by changing the focus from a balancing test to a search for common values, the analysis promises to be at once more tolerant of foreign mandatory laws and more realistic in assessing the conflict involved. 